DOI: 10.32844/2222-5374-2020-104-2.18

УДК: 342.9

Кінзбурська В. О., здобувач Харківського національного університету внутрішніх справ

\title{
ЗАГАЛЬНОДЕРЖАВНИЙ РІВЕНЬ ВЗАЕМОДІЇ ОРГАНІВ ВЛАДИ ТА ГРОМАДСЬКИХ ІНСТИТУЦІЙ
}

\begin{abstract}
Соціально-економічні зміни, які мають кардинальний характер в Україні, всебічна демократизація політичного життя суспільства обумовлюють два основні завдання суспільного розвитку. Приведення формату та способів державного управління у відповідність із світовими та європейським зокрема, тенденціям управлінської діяльності. Другим завданням є підтримання процесів формування громадянського суспільства у світлі динаміки демократичного розвитку країни. 3 огляну на такі завдання формування належного рівня взаємодії органів влади з населенням в лиці різноманітних громадських інституцій $\epsilon$ актуальним напрямком як наукової розробки, так і практичної реалізації повноважень у даній сфері. Враховуючи те, що взаємодія населення з державою проявляється у різних формах та реалізовується за допомогою ряду засобів та методів, варто наголосити, що сучасна тенденція розвитку провідних країн світу полягає в тому, що органи влади починають розглядатися в якості сервісних служб по відношенню до населення. В статті проаналізовано актуальність та необхідність комплексного підходу до науково-практичної розробки чітких механізмів здійснення ефективної взаємодії органів влади та громадських інституцій. Запропоновано почати таке дослідження саме з визначення рівневості взаємодії, а конкретно з їі окремого рівня загальнодержавного рівня взаємодії. Наголошено на сферах взаємодії, серед яких виділено нормотворчу, правозастосовчу та правоохоронну діяльність. Також акцентовано увагу на проведенні громадської експертизи в рамках нормотворчої діяльності органів державної влади. Варто наголосити, що такі механізми нормативно-врегульовані, однак їх ефективність досі залишається на досить низькому рівні. Також акцентовано увагу на тому, що одним із способів або форм взаємодії центральних органів державної влади та інституцій громадського суспільства $\epsilon$ делегування певного об'єму повноважень громадським інституціям. Також зазначається, що формою взаємодії також можливо розглядати процеси реалізації форм безпосередньої демократії.
\end{abstract}

Ключові слова: взаємодія влади; органи влади та населення; взаємодія з громадськими інституціями; загальнодержавний рівень взаємодї; форми взаємодіï.

Актуальність теми. Аналіз процесів взаємодії державних органів та інститутів громадського суспільства варто проводити і в контексті наукової розробки від її особливостей в залежності від різних факторів. 3 огляду 
на те, що теоретичний простір, в якому можливо досить широко та довго вести мову про різноманіття видів взаємодії, $є$ досить великим, поряд із ним варто здійснити дослідження і практичної складової даного питання. Саме реальність та дієвість механізмів взаємодії органів державної влади та інститутів громадянського суспільства свідчать про рівень розвитку громадянського суспільства і як наслідок демократичної держави.

Виклад основних положень. Визначення характерних особливостей кожного їх процесів взаємодії дає змогу більш повно та змістовно врегульовувати та визначати процеси здійснення такої взаємодії. Демократичність суспільства характеризується рівнем діалогу влади 3 суспільством, відкритістю і прозорістю влади, довіри громадськості до державних органів. Сучасне суспільство вимагає від Уряду (в широкому розуміння цього слова) таких якостей, як відкритість, прозорість, наявності функціонуючого зворотного зв'язку. Однак, існуючі правові механізми дуже часто фіксують недосконалість тих чи інших форм, методів таких взаємодій. А сама тема взаємодії влади з громадськістю більше переміщається в складову комунікації, а точніше PR-стратегій [4, с. 7]. Тому все більше актуальним і необхідним $є$ розробка ефективних механізмів взаємодії, яка матиме зворотній зв'язок.

Ще одним досить важливим аргументом з приводу актуальності всестороннього дослідження процесів взаємодії $\epsilon$ шлях України до децентралізації влади. В цьому контексті дуже вдалим вбачається характеристика механізмів взаємодії в залежності від територіального принципу поділу влади або існуючої системи органів державної влади, яка включає загальнодержавні органи, регіональні та місцеві елементи.

Організація взаємодії влади та населення через громадські інститути здійснюється в різних формах та з допомогою різних заходів. Рівневий поділ такої взаємодії проводиться 3 метою виокремлення головних завдань та формування окремих принципів для взаємодії на кожному рівні. Тому, з урахуванням викладеного більш детально зупинимося на кожному із наведених рівнів.

До того ж варто додати, що в якісний рівень взаємодії населення із органами влади також є достатньо залежним від виду взаємодії. Це також стосується і рівневого поділу, адже на загальнодержавному рівні взаємодії механізм організації такої діяльності характеризується у сучасному житті формалістськими ознаками. На відміну від цього місцевий рівень взаємодії можна характеризувати як реальний і такий, що наближується до партнерства.

Рівневий поділ видів взаємодії у контекстів системи органів влади також може використовуватися і для оцінки якості такої взаємодії. Найчастіше про взаємодію населення або громадських інституцій та органів влади іде мова, коли питання стосуються більш-менш локальних, місцевих питань. Тому дослідження питання рівневості взаємодії $\epsilon$ актуальним з точки визначення її ефективності та вироблення конкретних шляхів удосконалення.

Переходячи до взаємодії на державному (центральному) рівні варто підкреслити, що під нею розуміється суспільні відносини центральних органів державної влади та інституцій громадянського суспільства. 
В умовах плюралістичної демократії держава поступається частиною своїх повноважень в державній та управлінській сферах соціальної життєдіяльності самоорганізуючим та самоуправляючим структурам, які його утворюють. Очевидно, що сильна держава неможлива без розвиненого громадянського суспільства, яке стає дієвим чинником державотворення за умови конструктивного та соціально відповідального діалогу з державою в межах правового поля [15]. 3 цього виходить, що функціонування системи взаємодії громадських інституцій та органів державної влади є одним 3 головних завдань України у світі реформаторських змін. А відтак створення стратегічних документів, що підтверджують держану спрямованість на створення партнерських відносин із громадськими інституціями є вкрай актуальним.

Таким документом була Національна стратегія сприяння розвитку громадянського суспільства в Україні на 2016-2020 роки, однак її термін дії вже закінчено, а процес формування нової тільки розпочато. Однак варто наголосити, що ті стратегічні завдання та напрямки, на нашу думку, повинні залишитися без змін. Так, створення сприятливих умов для формування та інституційного розвитку організацій громадянського суспільства; забезпечення ефективних процедур участі громадськості під час формування та реалізації державної, регіональної політики, вирішення питань місцевого значення; стимулювання участі організацій громадянського суспільства в соціально-економічному розвитку України; створення сприятливих умов для міжсекторальної співпраці [13], - не можливо вважати досягнутими, адже і нині існує багато проблемних питань у цій царині. Поряд із завданнями Стратегією визначаються і принципи розбудови громадянського суспільства, одним з яких $є$ забезпечення конструктивної взаємодії органів влади та інституцій громадянського суспільства, а також сприяння тому, щоб громадськість безпосередньо приймала участь у формуванні державної політики.

3 огляду на актуальність проблеми налагодження партнерських відносин між владою та громадськістю у 2016 р. було створено новий на той час інститут - Координаційну раду сприяння розвитку громадянського суспільства, яка $є$ консультативно-дорадчим органом при Президентові України [8]. Персональний склад даної ради передбачає половину її членів - представників організацій громадянського суспільства, що свідчить про спробу залучення громадськості до формування державної політики, навіть у сфері розвитку партнерських відносин із суспільством. На нашу думку, існування такого органу є виправданим та необхідним, однак викликає сумнів реальність такої форми взаємодії особливо на загальнодержавному рівні. В даному випадку важливо пам'ятати про принципи пропорційності представництва в таких органах. Така форма взаємодії повинна враховувати інтереси усіх верств населення в залежності від багатьох ознак: території проживання, соціальної, релігійної або будь-якої іншої ознаки. Цього важко досягти в умовах систематичного оновлення механізмів взаємодії та відсутності стійких та розвинутих інституцій громадського суспільства.

Однак нині, в умовах реформаторських змін суспільно-політичної ситуації в країні існує декілька головних форм взаємодії центральних органів державної влади із інституціями громадянського суспільства. До 
таких форм віднесено взаємодію у нормотворчій, правозастосовчій та правоохоронній діяльності держави.

У нормотворчій діяльності держави, яка забезпечується участю у розробленні та обговоренні проектів нормативно-правових актів. Участь у правотворчій діяльності $\epsilon$ найпоширенішою формою участі громадських організацій у державному управлінні.

Громадське обговорення проектів нормативних актів $€$ обов>язковим етапом нормотворчого процесу в системі органів виконавчої влади. Консультації з громадськістю в нормотворчому процесі проводяться 3 метою залучення громадян до участі в управлінні державними справами, надання можливості для їх вільного доступу до інформації про діяльність органів виконавчої влади, а також забезпечення гласності, відкритості та прозорості в діяльності цих органів. Проведення консультацій 3 громадськістю має також сприяти налагодженню системного діалогу органів виконавчої влади і громадськості, підвищенню якості підготовки та прийняття рішень з важливих питань державного і суспільного життя з урахуванням думки громадськості, створенню умов для участі громадян у розробленні проектів таких рішень. Консультації з громадськістю проводяться $з$ питань, що стосуються суспільно-економічного розвитку держави та життєвих інтересів широких верств населення [2].

Для прикладу варто навести п. 4.3 Інструкції з організації нормотворчої діяльності в Міністерстві внутрішніх справ України, де зазначено, що для підготовки проектів нормативних актів MBC з найбільш важливих (концептуальних) питань службової діяльності органів та підрозділів внутрішніх справ, а також актів, що видаються спільно декількома міністерствами чи іншими центральними органами виконавчої влади, розпорядчим документом керівництва МВС створюється робоча група (комісія) у складі досвідчених кваліфікованих працівників, які на період підготовки проектів у складі робочої групи можуть звільнятися від виконання своїх функціональних обовьязків, а також науковців і представників громадськості (за їх згодою) [10]. Таке положення свідчить про те, що взаємодія Міністерства внутрішніх справ їх громадськістю перебуває на достатньому рівні у сфері участі у нормотворчій діяльності.

Пункт 5 Порядку проведення консультацій 3 громадськістю 3 питань формування та реалізації державної політики також визначає, що «консультації з громадськістю організовує і проводить орган виконавчої влади, який $є$ головним розробником проекту нормативно-правового акта або готує пропозиції щодо реалізації державної політики у відповідній сфері державного і суспільного життя» [9]. Це є ще одним підтвердженням того, що процес залучення громадськості до участі у правотворчій діяльності $є$ актуальним та реальним. Перелік напрямів такої взаємодії $є$ досить широким та не є вичерпним, охоплює майже усі сфері суспільного життя в державі.

Ще однією формою взаємодії у процесі норматворення є проведення громадських експертиз, які передбачають визначення як загальної оцінки діяльності органу влади, так і участі у формуванні державної політики шляхом консультування та обговорення проєктів нормативно-правових актів. 
3 іншого боку, можна вести мову і про форми безпосередньої демократії як один із видів взаємодії на загальнодержавному рівні. Так, у контексті нормотворчості процес обрання представників до парламенту можна вважати механізмом впливугромадськості через своїхпредставників формування державної політики, особливо у сфері нормотворчості. Референдум, по суті, $\epsilon$ способом з>ясування думки населення 3 певних питань. Тобто під час здійснення референдуму процес взаємовідносин явно проявляється. Однак, в сучасних умовах такий механізм хоча і $\epsilon$ ефективним, в той же час потребує досить великих матеріальних видатків, що, в умовах суспільної кризи може бути розціненою суспільством в негативному ракурсі.

Також на загальнодержавному рівні визначена можливість передання певного об〉єму повноважень громадським інституціям. Варто наголосити, що переважна більшість вчених визначають органи місцевого самоврядування як окремий вид громадських інституцій. Відповідно до Закону України «Про місцеве самоврядування в Україні» виконавчим органам рад (органів місцевого самоврядування) делеговано ряд повноважень центральних органів державної влади. 3 огляду на доктринальне розуміння сутності органів місцевого самоврядування, саме під час реалізації таких делегованих повноважень і здійснюється процес взаємодії органів державної влади та громадських інституцій у їх класичному розумінні.

В правозастосовній сфері ще однією ефективною формою взаємодії є залучення громадськості до контрольно-дорадчої діяльності. Моніторинг діяльності органів влади, громадська експертиза, створення консультативно-дорадчих структурних елементів у складі органів влади, - все це є формами участі громадськості у правозастосовній діяльності органів влади.

Неодмінними складовими стабільності взаємовідносин влади та інститутів громадянського суспільства $\epsilon$ досконалість нормативноправової бази, відкритість та прозорість діяльності владних структур, врахування громадської думки при застосуванні нових форм і технологій роботи 3 громадськістю, залучення громадян до участі в реалізації муніципальних і регіональних соціальних програм [3, с. 284]. Наявність нормативно-правових підстав здійснення взаємодії з громадянськими інституціями $є$ обов>язковим компонентом налагодження таких механізмів, адже будь-яка діяльність органів влади, а особливо процес взаємодії має бути чітко регламентований.

Правоохоронна сфера діяльності також $є$ середою для взаємодії органів державної влади та громадських інституцій. Можливістьучасті громадськості в охороні громадського порядку (Закону України «Про участь громадян в охороні громадського порядкуі державного кордону» [14]), правомочність складання протоколів про адміністративні правопорушення членами громадських формувань або громадськими інспекторами (ст. 255 КУПАП [6]), реалізація контрольних заходів щодо діяльності правоохоронних органів, - все це $є$ формами взаємодії громадськості та органів влади у правоохоронній сфері. Варто підкреслити, що організація та унормування такого роду взаємодії може здійснюватися на територіальному або 
місцевому рівнях, однак чітке нормативне встановлення порядку та форм такої взаємодії визначають центральні органи виконавчої влади.

Проведеним аналізом законодавства та наукової літератури у сфері взаємодії інститутів громадського суспільства та органів державної влади встановлено переважне існування контрольно-дорадчих органів та односторонньою взаємодією, яка виявляється у відкритості діяльності органів влади [11] та обов'язковості оприлюднення інформації про діяльність органів виконавчої влади [12]. Як підсумок з цього: визначення якості та ефективності взаємодії органів державної влади та інституцій громадянського суспільства на загальнодержавному рівні переважно має формальнийхарактер таздійснюєтьсяуформідорадчоїабоконсультативної діяльності (відсутність обов язковості виконання рішень громадськості) та шляхом звітності органів влади перед населенням, що також не передбачає обов язкового зворотного зв>язку. Єдиним виключенням можна говорити про існування та функціонування політичних партій, які на думку науковців $[5 ; 7 ; 1] є$ яскравим прикладом інституцій, які здійснюють своєрідну взаємодію із органами влади в інтересах суспільства та громадськості.

\section{СПИСОК ВИКОРИСТАНИХ ДЖЕРЕЛ}

1. Абетка політична. Громадянське суспільство і політика: навчальний посібник. За наук. ред. док. наук держ. упр. О.В. Радченка, [автори-упоряд. А.В. Карташов, О.В. Радченко], вид. 11-е, доп. і перероб. Київ : 2016.48 с.

2. Взаємодія держави та інститутів громадянського суспільства: роз'яснення Міністерств.а юстиції України від 03.02.2011 URL: https:// zakon.rada.gov.ua/laws/show/n0018323-11\#Text

3. Гавкалова Н.Л., Грузд М.В. Взаємодія органів публічної влади та інститутів громадянського суспільства. Актуальні проблеми економіки. № 10(160). 2014. С. 281-290.

4.3бірник звітів за результатами оцінки діяльності органів виконавчої влади за напрямком «взаємодія з громадськістю»: Збірка / Упоряд.: Любов Паливода Київ: [БФ “Творчий центр ТЦК”] 2018. 72 с.

5. Карпяк О. Громадянське суспільство у сучасній Україні (політикоправовий аспект). Вісник Львівського університету. Серія філос.-політолог. студії. 2017. Вип. 14. С. 126-133

6. КодексУкраїни проадміністративні правопорушення: від 07.12.1984 № 8073-X URL: https://zakon.rada.gov.ua/laws/show/80732-10\#top

7. Мошинський Р. Інститути громадянського суспільства в Україні: соціально-правова спрямованість політичних процесів та їх вплив на національну безпеку. Вісник Національної академії державного управлінняпри Президентові України. 2013. № 2. С. 184-192. URL: http:// nbuv.gov.ua/UJRN/Vnadu_2013_2_25

8. Питання Координаційної ради сприяння розвитку громадянського суспільства: Указ Президента Укарїни від 04.11.2016 № 487/2016 URL: https://zakon.rada.gov.ua/laws/show/487/2016\#Text

9. Про забезпечення участі громадськості у формуванні та реалізації державної політики: Постанова Кабінету Міністрів України від 3 листопада 2010 p. № 996. URL: https://zakon.rada.gov.ua/laws/show/996-2010$\%$ D0\%BF\#top 
10. Про затвердження Інструкції з організації нормотворчої діяльності в Міністерстві внутрішніх справ України: наказ Міністерства внутрішніх справ України від 27.07.2012 № 649. URL: https://zakon.rada.gov.ua/rada/ show/v0649320-12\#Text

11. Про заходи щодо подальшого забезпечення відкритості у діяльності органів виконавчої влади: постанова Кабінету Міністрів України від 29 серпня 2002 р. № 1302. URL: https://zakon.rada.gov.ua/laws/ show/1302-2002-\%D0\%BF\#Text

12. Про Порядок оприлюднення у мережі Інтернет інформації про діяльність органів виконавчої влади: постанова Кабінету Міністрів України від 4 січня 2002 р. № 3. URL: https://zakon.rada.gov.ua/laws/show/3-2002$\%$ D0\%BF\#Text

13. Про сприяння розвитку громадянського суспільства в Україні: Указ Президента Укарїни від 26.02.2016 № 68/2016 URL: https://zakon.rada. gov.ua/laws/show/68/2016\#top

14. Про участь громадян в охороні громадського порядку і державного кордону: Закон України від 22.06.2000 № 1835-III URL: https://zakon.rada. gov.ua/laws/show/1835-14\#Text

15. Семьоркіна О.М. Взаємодія держави та інститутів громадянського суспільства. URL: https://minjust.gov.ua/m/str_33679

\section{Kinzburska}

\section{NATIONAL LEVEL OF INTERACTION OF BODIES AUTHORITIES AND PUBLIC INSTITUTIONS}

Socio-economic changes, which have a cardinal character in Ukraine, comprehensive democratization of the political life of society determine the two main tasks of social development. Bringing the format and methods of public administration in line with world and European in particular, management trends. The second task is to support the processes of civil society formation in the light of the dynamics of democratic development of the country. In view of such tasks, the formation of an appropriate level of interaction between the authorities and the population in the face of various public institutions is an important area of both scientific development and practical implementation of powers in this area. Given that the interaction of the population with the state manifests itself in various forms and is implemented through a number of means and methods, it should be emphasized that the current trend of the world's leading countries is that the authorities are beginning to be seen as services to the population. The article analyzes the relevance and necessity of a comprehensive approach to the scientific and practical development of clear mechanisms for effective interaction between government and public institutions. It is proposed to start such a study with the definition of equality of interaction, and specifically with its individual level - the national level of interaction. Emphasis is placed on the areas of cooperation, among which are normative, law enforcement and law enforcement activities. Emphasis is also placed on conducting public expertise in the framework of rule-making activities of public authorities. It should be noted that such mechanisms are regulated, but their effectiveness still remains quite low. 
Emphasis is also placed on the fact that one of the ways or forms of interaction between central government bodies and civil society institutions is the delegation of a certain amount of authority to public institutions. It is also noted that the form of interaction can also be considered the processes of implementation of forms of direct democracy.

Keywords: interaction of power; authorities and the population; interaction with public institutions; national level of interaction; forms of interaction. 